\title{
Analysis of temporal variation characteristics on water quality along Code River, Indonesia
}

\author{
Joni Aldilla Fajri ${ }^{1, *}$, Muhammad Haikal A ${ }^{1}$, Putri Nurjanah $^{1}$, Mayu Dwi A ${ }^{1}$, Mulyani Zahra \\ $\mathrm{P}^{1}$, Priscaningtyan ${ }^{1}$, Rangga Pratama $^{1}$, Arsitika Builda P.A ${ }^{1}$, Arief Muhanza ${ }^{1}$, Eko \\ Siswoyo $^{1}$, Aster Rahayu ${ }^{2}$, Any Juliani ${ }^{1}$, and Luqman Hakim ${ }^{1}$ \\ ${ }^{1}$ Faculty of Civil Engineering and Planning, Universitas Islam Indonesia, Kaliurang, 44488, Indonesia \\ ${ }^{2}$ Industrial Technology Faculty, Ahmad Dahlan University, 55164, Indonesia
}

\begin{abstract}
Physicals, chemicals, and microbial parameters were analysed along the Coder River to reveal the temporal influence on water quality characteristics. From December 2017 to March 2018, we collected twice a month surface water sample at the nine monitored sampling site. The results indicate that the temporal factor has a significant impact, particularly in wet and dry seasons, on increasing the chemical oxygen demand (COD), ammonia-nitrogen $\left(\mathrm{NH}_{3}-\mathrm{N}\right)$, total coliform (TC), and faecal coliform (FC) above the local government standard. Overall, the water quality in the Code River is mainly influenced by the anthropogenic pollution sources that did not decrease during the dry season because of the low water flow.
\end{abstract}

Keywords: anthropogenic, Code River, water quality, temporal data

\section{Introduction}

Code River Watershed is a vital river flowing in the heart of Yogyakarta City, Indonesia. It is being used by the Yogyakarta people for several purposes such as irrigation, fishery and drinking water source. The total length of Code River reaches $45 \mathrm{Km}$ where the upstream is located at the hill slope of an active volcano and that is covered by forestry areas. While the downstream of Code Rive is a Greek to the Opak river, which as is one of the widest and longest rivers in Yogyakarta Province. The watershed along the Code River has changed for different purposes. The watershed along the Code River is used for the different purposes. Changes in land use pattern have impacted water quality if the local government did not control and pretend the way to protect surface water.

In a few decades earlier, the water quality of Code River was reported in worse condition because of many introductions of pollutant and alien wastewater pipes [1-2]. Moreover, Puspitasari [3] reported that several wells in the Code River Watershed were contaminated by Manganese $(\mathrm{Mn})$ and Nitrate $\left(\mathrm{NO}_{3}{ }^{-}\right)$, which resulted in bad smelling in the well waters.

Moreover, the location of Yogyakarta province in the south east of Java Island and the highland area, it causes strong seasonal variations in precipitation. The major drainage networks system in central Yogyakarta that are connected to the Code River including wide

\footnotetext{
Corresponding author: joni.af@uii.ac.id
} 
drainages from other areas as well. These conditions can probably affect the water quality trends along Code Rive. Therefore, the purpose of this study is to evaluate the influence of temporal factors: dry and wet season period and to reveal major source of water pollutants.

\section{Materials and methods}

\subsection{Study area}

The Code River watershed is located in Yogyakarta province between the longitude 7o36'58.61"S and 110o24'55.24'T and the latitude 7'53'13.74"S and 110 23'11. 49" E. The Code River flows through Yogyakarta City and two districts (Sleman and Bantul districts) from the North to the South. This river was classified into three segments based on the water quality classification, which each segment having a different landscapes and land use (Table 1). The upstream area is located near an active volcano and is dominated by forestry areas and traditional sand mining by local people; the middle stream area is an urban area, and all the drainage networks and some household waste pipes flow to the Code River. The downstream area is characterized by agricultural and local industry areas before Code River join the Opak River.

Table 1. Characteristics of land use in the Code River watershed

\begin{tabular}{cll}
\hline No. & Sampling site & \multicolumn{1}{c}{ Main land use character } \\
\hline 1 & Site 1 & Near to volcano and forestry \\
2 & Site 2 & Agricultural areas and household \\
3 & Site 3 & Urban and near a public university \\
& & Urban, near a public university and an \\
4 & Site 4 & inlet drainage of neighbor area \\
5 & Site 5 & Urban and near a city hosphital \\
6 & Site 6 & Urban and near a tourism area \\
7 & Site 7 & Urban \\
8 & Site 8 & Agricultural area and local industry areas \\
9 & Site 9 & Agircultural areas and tribututary \\
\hline
\end{tabular}

\subsection{Monitored parameters and analytical methods}

The nine spatial sampling sites were monitored for six months from December 2017 to May 2018 (Fig. 1), where each site represented a specific the land use and different characteristics Code River watershed. Water sampling was conducted twice in a month (once in June) to obtain average temporal data along the river. The river flow was measured using vertical-axis current meter following the Indonesia Standard for River Water Monitoring (SNI 6989.57:2008). In order to obtain real water quality data in the river, water samples were collected and mixed from at least three points at each site, and stored in a $5 \mathrm{~L}$ polypropylene bottle. All bottles were kept in a cooling box during transportation to the laboratory and were stored in the $5{ }^{\circ} \mathrm{C}$ refrigerator before measured in the next day. Physical parameters including the hydrogen ion concentration $(\mathrm{pH})$, electrical conductivity 
(EC), temperature (Tw), and turbidity (Turb.) were measured onsite using water probe meter. In addition, dissolved oxygen (DO), biological oxygen demand, ammonia-nitrogen, faecal coliform, total coliform), and Escherichia coli (E. coli) were measured in the laboratory followed the Indonesian standard (SNI) as shown in Table 2.



Fig. 1. Study area and spatial distribution of sampling sites within watershed of Code River.

Table 2. Parameter indices used in this study

\begin{tabular}{clll}
\hline No. & \multicolumn{1}{c}{ Parameter } & \multicolumn{1}{c}{ Unit } & \multicolumn{1}{c}{ Method } \\
\hline 1 & Flow water & $\mathrm{m}^{3} / \mathrm{s}$ & Electrical device \\
2 & Electric conductivity & $\mu \mathrm{S} / \mathrm{m}$ & Conductometry \\
3 & Turbidity & $\mathrm{NTU}$ & Portable turbidity meter \\
4 & $\mathrm{COD}$ & $\mathrm{mg} / \mathrm{L}$ & Spectrometry \\
5 & $\mathrm{DO}$ & $\mathrm{mg} / \mathrm{L}$ & Titrimetry \\
6 & $\mathrm{NH}_{3}-\mathrm{N}$ & $\mathrm{mg} / \mathrm{L}$ & Spectrometry \\
7 & Fecal coliform & $\mathrm{MPN} / 100 \mathrm{~mL}$ & Multiple tube fermentation \\
8 & Total coliform & $\mathrm{CFU} / 100 \mathrm{~mL}$ & Spread agar \\
9 & E. coli & $\mathrm{CFU} / 100 \mathrm{~mL}$ & Spread agar \\
\hline
\end{tabular}


Precipitation data were obtained from the Indonesian Agency for Meteorology, Climatology and Geophysics (BMKG) for Yogyakarta area. The precipitation data were collected from December 2017 to June 2018. However, the wet season mainly occurred from late October to late March. The precipitation data were averaged on the three days before each sampling date because we assumed that water quality may alter after rain water. Moreover, the data obtained after March was in the transition seasonal period before entering the dry season.

\subsection{Statistical analysis}

A statistical analysis, one-way ANOVA, were performed using a statistical analysis program, SPSS (ver.21) to evaluate the variance at each sampling site and to evaluate surface water quality changes.

\section{Results and discussion}

\subsection{Temporal data and physical parameters}

\subsubsection{Precipitation}

In this study, the influence of temporal factor especially during wet season is one of the key factors that may influence the water quality in the river water. Figure 2 shows the daily precipitation rate during the study period. High precipitation was recorded in December 2017 (98 mm). During January to March, precipitation rates were between 25 to $11 \mathrm{~mm}$. However, there is almost no precipitation data obtained from April to May 2018. This graph shows that January and February are wet season while from March to May are dry season.

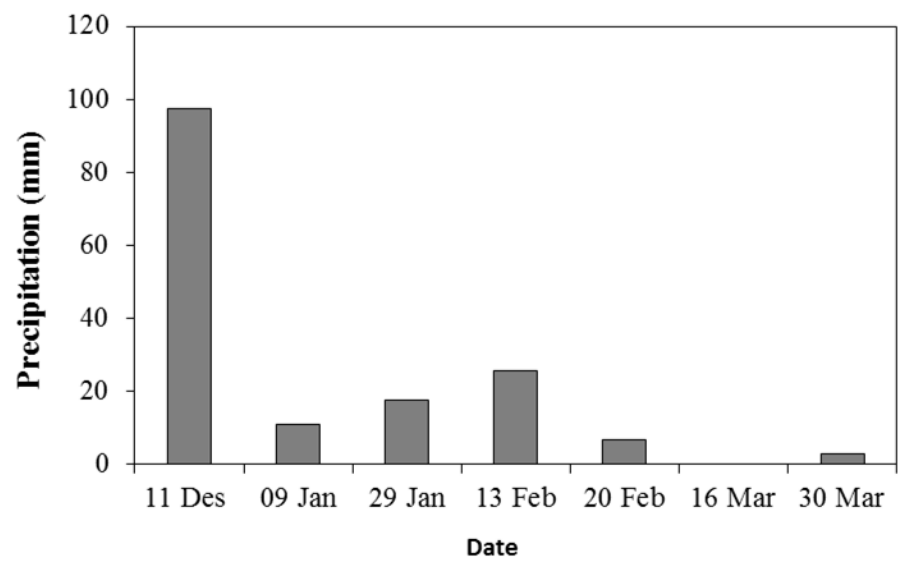

Fig. 2. The precipitation rate the during study period from December 2017 to March 2018. Source : BMKG, Yogyakarta, 2018. 


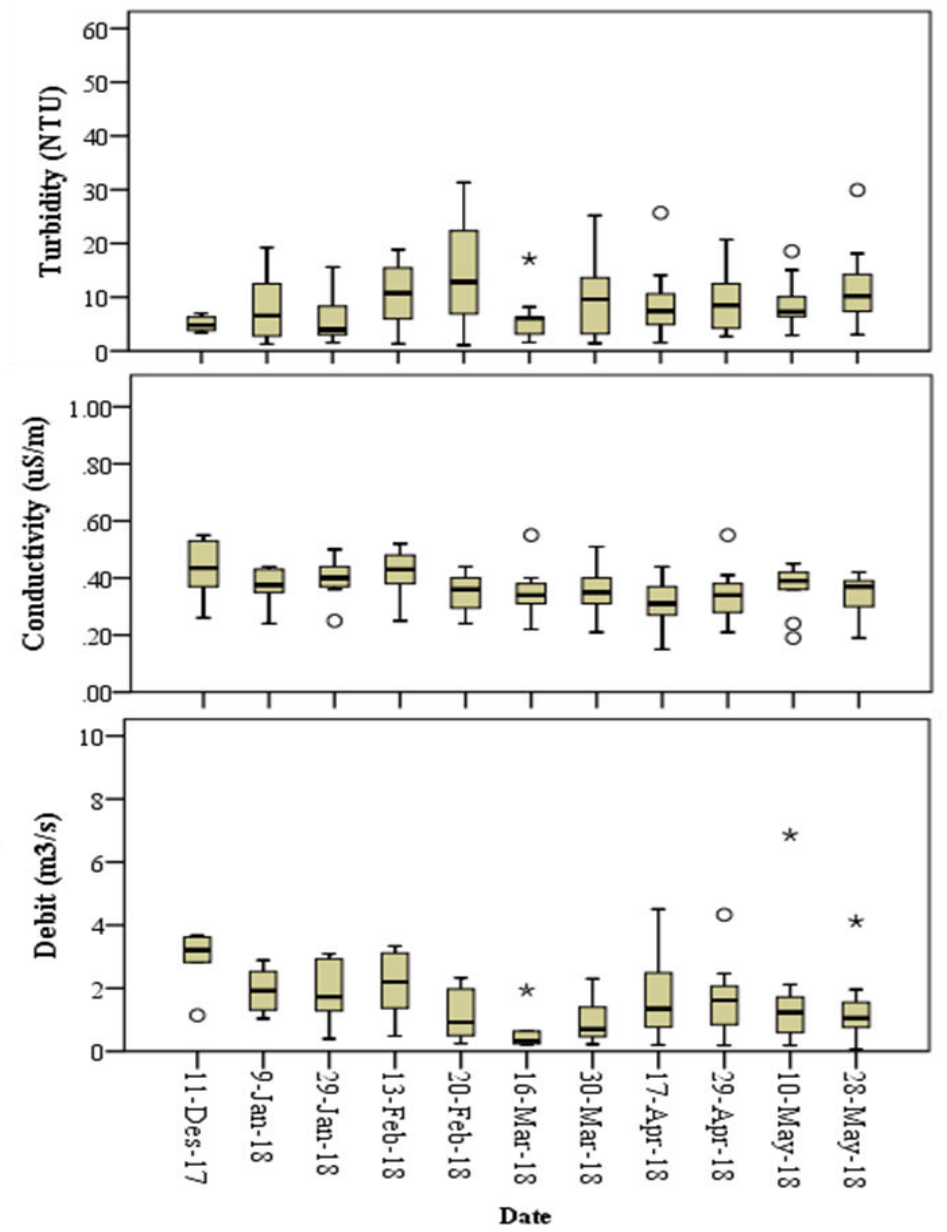

Fig. 3. Physical characteristics along river during the study period

\subsubsection{Physical parameters}

The physical parameters were analyzed to study the physical characteristics including flow water, turbidity, and conductivity along Code River (Fig. 3). The high flow water in river was recorded in Dec, $11^{\text {th }} 2017\left(3.3 \mathrm{~m}^{3} / \mathrm{s}\right)$ compared to other sampling times. While, the average flow water in wet season $\left(2.1 \mathrm{~m}^{3} / \mathrm{s}\right)$ were higher than in the dry season $\left(1.5 \mathrm{~m}^{3} / \mathrm{s}\right)$, which indicated that precipitation in the wet season strongly influenced water flowing to the watershed through the drainages systems.

The mean conductivity and turbidity concentrations showed no significant $(p>0.005)$ differences between wet season and dry season (Fig. 3). The mean EC and turbidity concentrations were higher in the wet season period, around $0.40 \mathrm{~ms} / \mathrm{m}$ and $15 \mathrm{NTU}$, respectively, compared in the dry season, $0.34 \mathrm{~ms} / \mathrm{m}$ and $10 \mathrm{NTU}$, respectively. The high precipitation potentially flushed many substances including organic components and inorganic ions that changed the value of turbidity and electric conductivity. These inorganic ions altered the $\mathrm{pH}$ and $\mathrm{EC}$ in the river water quality. 


\subsection{Chemical-nutrient related parameters}

The average $\mathrm{DO}, \mathrm{COD}$ and $\mathrm{NH}_{3}-\mathrm{N}$ concentrations were significant higher $(p<0.005)$ in the dry season than in the wet season (Fig. 4). Average concentrations of DO, COD, and $\mathrm{NH}_{3}-\mathrm{N}$ in dry season ranged from 4 to $9 \mathrm{mg} / \mathrm{L}, 60$ to $80 \mathrm{mg} / \mathrm{L}$, and 3.5 to $4.8 \mathrm{mg} / \mathrm{L}$, respectively. While during wet season, the average concentration of DO, COD and $\mathrm{NH}_{3}-\mathrm{N}$ were around 5 to $6.3 \mathrm{mg} / \mathrm{L}, 38$ to $80 \mathrm{mg} / \mathrm{L}$, and 0.8 to $1.6 \mathrm{mg} / \mathrm{L}$, respectively. Contrary to the water quality standard for Code River based on the Governance regulation (Perda DIY, No. 20, 2008), the COD exceeded the maximum level standard $(50 \mathrm{mg} / \mathrm{L})$ for third classification of river water quality for fishery and agricultural. The maximum value of $\mathrm{NH}_{3}-\mathrm{N}$ is not defined in the current Governance regulation, but the detected concentrations were much higher than regulation from Ministry of Indonesian Environment that $1 \mathrm{mg} / \mathrm{L}$ is recommended for the agricultural and fishery river class.
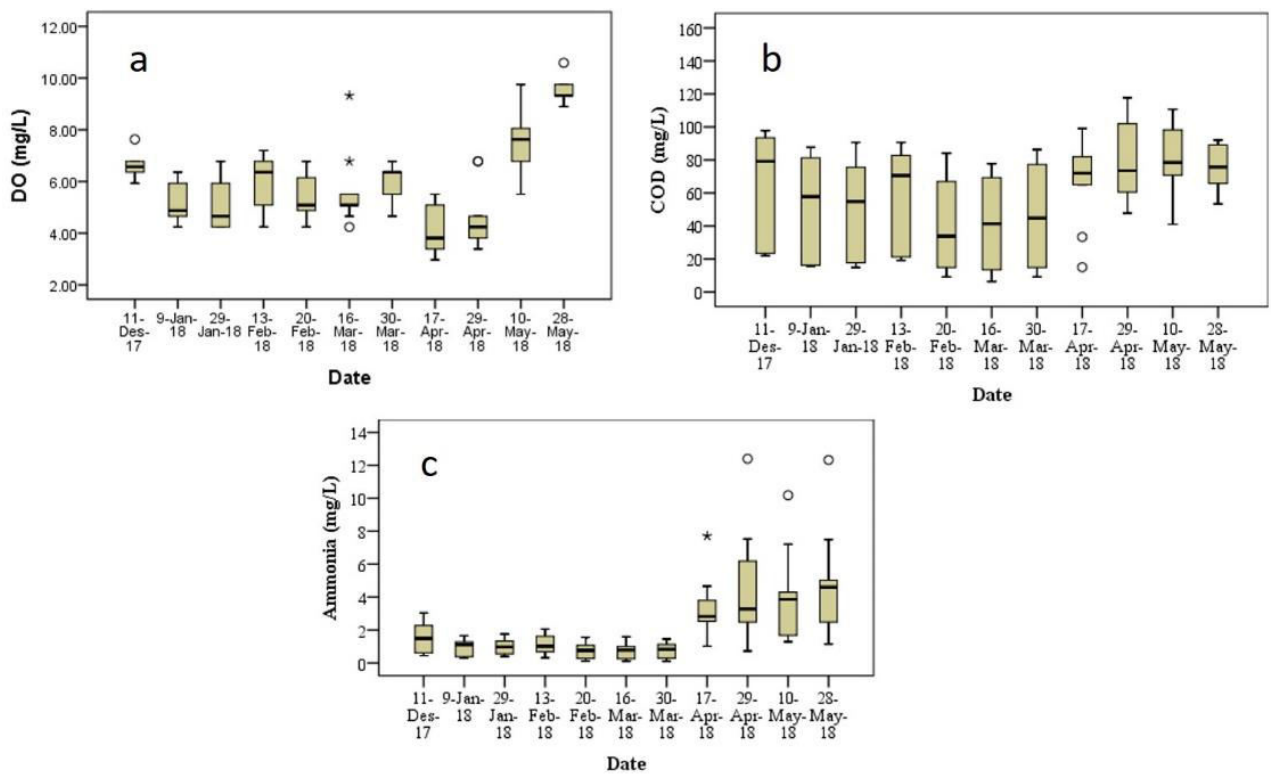

Fig. 4. Box plot diagrams showing of the DO (a), $\mathrm{COD}(\mathrm{b})$, and Ammonia $\left[\mathrm{NH}_{3}-\mathrm{N}\right]$ (c) in Code River water.

The oxygen level during wet season were sufficiently high as high water flow as increases water level and turbulence. In this study, water temperature showed negative correlation with DO, which indicated that the low water temperature may increase the DO level [4]. High concentrations of $\mathrm{COD}$ and $\mathrm{NH}_{3}-\mathrm{N}$ were an indicator of anthropogenic pollution from untreated household effluents induced to the water bodies. $\mathrm{COD}$ and $\mathrm{NH}_{3}-\mathrm{N}$ can decrease due to the increasing water flow as the effect of dilution factor. Contrary, during low water level in the dry season, the purification and dilution factor fail to reduce the organic pollution naturally [5-6].

\subsection{Microbial concentration}

Concentrations of microorganism including TC, FC, and E. coli are displayed in the Fig. 5. E. coli concentrations were not significantly difference in concentration at each sampling time. Contrary, the TC and FC showed significance higher concentrations in dry season 
compared to the wet season. The average E. coli concentrations were around 120 to 1000 $\mathrm{CFU} / 100 \mathrm{~mL}$ for both wet and dry season. The average TC and FC concentrations ranged from $5.9 \times 10^{4}$ to $5.5 \times 10^{5} \mathrm{CFU} / 100 \mathrm{~mL}$, and $2 \times 10^{4}$ to $8 \times 10^{4} \mathrm{MPN} / 100 \mathrm{~mL}$, respectively, in the wet season and from $6.8 \times 10^{5}$ to $3.7 \times 10^{5} \mathrm{CFU} / 100 \mathrm{~mL}$ and $2.4 \times 10^{5}$ to $1.5 \times 10^{5}$ MPN/100 mL, respectively, in the dry season.
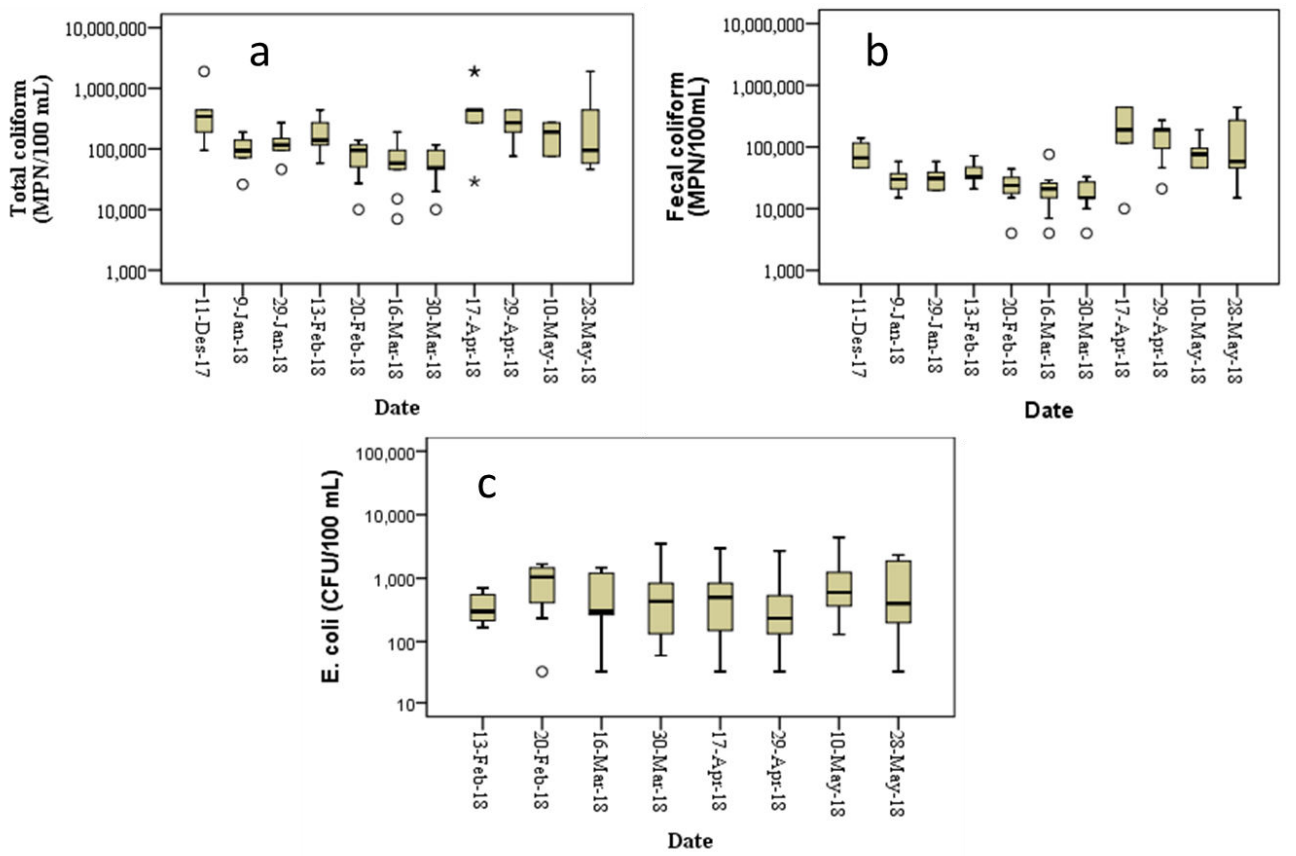

Figure 5 Box plot diagrams showing of the TC (a), FC (b), and E. coli (c) of Code River water quality

The concentrations of TC and FC along the Code River are beyond the Governance regulation for river water quality standard at all classes, i.e. TC and FC should be below $1 \times$ $10^{4} \mathrm{CFU} / 100 \mathrm{~mL}$ and $2 \times 10^{3} \mathrm{MPN} / 100 \mathrm{~mL}$, respectively (Perda DIY, No 28/2008). The faecal bacteria coliform (FIB) is one of the major indicator of pollution from domestic household. They presence in high concentrations of TC and FC in the surface water might reveal the existence of virus and pathogenic bacteria that can induce health risk by waterborne disease transmission [7]. During dry season and low water level, the FIB increased due to the low dilution factor and at this appropriate condition, the FIB number may duplicate particularly in the sediment phase [8].

\section{Conclusions}

The study on temporal influence on river water quality along Code River Watershed revealed the difference water quality condition in the wet and dry season period. The wet season generally is a period of as good water quality conditions to physico-chemicalmicroorganism parameters. High water flow that can dilute the pollutant substances appear the main process for keeping contaminant concentration low. The opposite holds to dry season when high concentrations of anthropogenic pollution particularly $\mathrm{NH}_{3}-\mathrm{N}$ and faecal 
coliform bacteria were detected. This introduction of untreated domestic wastewater to the Code River show as the major pollution sources that can decrease the water quality. Therefore, it is important to create a policy for water quality protection that is associated with urban development to reduce the inflow of untreated wastewater to the Code River.

\section{References}

1. Bapedalda. (2000). Laporan Akhir: Pengkajian daya tampung beban air sungai. BAPEDALDA Propinsi DIY dan Pusat Studi Lingkngan Hidup Universitas Gadjah Mada. Yogyakarta.

2. Imroatushshoolikhah. (2013). Kajian Kualitas Air Sungai Code Provinsi Daerah Istimewa Yogyakarta. MGI Vol. 28, No. 1, Maret 2014 (23-32).

3. Pustiptasari. (2007). Dampak pencemaran udara terhadap kesehatan lingkungan dalam Perspektif Hukum Lingkungan (Studi Kasus Sungai Code di Kelurahan Wirogunan Kecamatan Mergangsan dan kelurahan Prawirodirjan Kecamatan Gondomanan, Yogyakarta. Mimbar Hukum, 21:23-24.

4. Kannel, P. R., Lee, S., Lee, Y.-S., Kanel, S. R., \& Khan, S. P. (2007). Application of Water Quality Indices and Dissolved Oxygen as Indicators for River Water Classification and Urban Impact Assessment. Environmental Monitoring and Assessment, 132(1-3), 93-110. http://doi.org/10.1007/s10661-006-9505-1.

5. Sun, W., Xia, C., Xu, M., Guo, J., \& Sun, G. (2016). Application of modified water quality indices as indicators to assess the spatial and temporal trends of water quality in the Dongjiang River. Ecological Indicators, 66, 306-312. http://doi.org/10.1016/j.ecolind.2016.01.054.

6. Xu, J., Jin, G., Tang, H., Zhang, P., Wang, S., Wang, Y. G., \& Li, L. (2018). Assessing temporal variations of Ammonia Nitrogen concentrations and loads in the Huaihe River Basin in relation to policies on pollution source control. Science of the Total Environment. http://doi.org/10.1016/j.scitotenv.2018.05.395.

7. Fajri, J. A., Yamada, T., Setiyawan, A. S., \& Li, F. (2015). Evaluation of Water and Sediment Quality in Open Channels that Receive Effluent from Johkasou Facilities, 13(3), 207-219.

8. Bai S. and Lung, W. S. (2005). Modeling sediment impact on the transport of faecal bacteria. Water Res., 39 (20), 5232-5240. 